The remaking of the EU's borders and the images of European architecture

Jan Zielonka

St Antony's College, University of Oxford, OX2 6JF Oxford, UK

Jan Zielonka is Professor of European Politics at the University of Oxford and Ralf Dahrendorf Fellow at St Antony's College 


\section{The remaking of the EU's borders and the images of European architecture}

The article argues that it is impossible to explain the series of existential crises confronting present-day Europe without reference to the changing nature of borders. Unbounding and rebounding prompted by transnational and technological pressures reconfigures the relationship between territory, authority, and rights in Europe. It produces new winners and losers. It changes the geography of power and makes European institutions look inadequate if not obsolete. The article tries to utilize recent studies in the field of geography, economics, and communication to understand the evolution of European integration. Four spatial models or architectural designs are envisaged: variable geometry, ordo-liberal empire, functional networks, and cascading pluralism.

Keywords: borders; European Union, differentiated integration; territory; authority; rights

Most conflicts in Europe’s modern history were about borders. European integration was said to overcome this legacy. Borders were to be opened if not eliminated altogether. As we approach the sixtieth anniversary of the Treaty of Rome borders are again at the centre of political contestation. Where do the borders of the EU lie? Which states are in and which are out? Who should be in charge of border controls? Who and what can cross EU borders? How can borders be protected? Are we still masters within our borders? Who are we, in the Europe of open or porous borders? Europeans are increasingly preoccupied with these questions and they are unable to find common answers. As a consequence, conflicts abound with no resolution in sight.

Some experts argue that the integration project has proven fundamentally flawed: it is impossible to build a genuine community in an open-ended, multi-layered, and multi-cultural

polity such as the EU. ${ }^{1}$ Going back to nation-states with their clear borders, national identity, 
and directly elected government is therefore seen as the best way to overcome the current impasse. The result of the Brexit referendum is a good example of this reasoning.

Other experts argue that the integration project did not go far enough: nation states are still in charge of the EU and unable to find common solutions to trans-border questions. Delegating more powers to the European centre should in their view end the current paralysis and help Europe to overcome the ghosts of Westphalia (Tsoukalis 2016; Verhofstadt 2017).

The above dichotomy is false in my view; Europe’s current problems are chiefly caused by geopolitical, economic, and technological developments, which changed the shape and nature of borders. This process of "unbounding," and "rebounding” redefined the relationship between territory, authority, and rights in Europe. ${ }^{2}$ It produced new winners and losers. It changed the geography of power and made European institutions look inadequate if not obsolete altogether. In other words, the integration project has failed to adjust to ongoing changes, but the Eurosceptic hope that nation-states will cope with unbounding any better is quite illusory, I will argue. Europe is a highly interdependent melting pot condemned to some sort of integration. This article will try to envisage which kind of integration will emerge from the current disarray, putting borders at the centre of the analysis(Christiansen and Jørgensen 2000).

The article tries to utilize recent studies in the field of geography, economics, and communication to understand the evolution of European integration. Four spatial models or architectural designs are envisaged: variable geometry, ordo-liberal empire, functional networks, and cascading pluralism. Each of them is led by different actors and exhibits different governance patterns. Each of them defies the "official” notion of European architecture and suggest a re-definition of the costs and benefits of European integration. The analysis is tentative if not speculative. Its aim is to stimulate our imagination with no ambition to predict the future of the EU and its institutional structures. The current model of integration may well 
be doomed, but we do not know which of the proposed models of integration is likely to prevail, if any.

\section{Borders, states, and nations}

Borders delimit individual spaces, but they are not just lines on a map. ${ }^{3}$ They represent complex institutions determining the link between the territory, authority, and rights (Sassen 2008). Borders define arrangements for market transactions, coercion powers, politico-administrative entitlements, and communication clusters. These arrangements can be formal or informal to various degrees, but they are not given or stable; they are subject to historical change driven by technological, economic, social, cultural, political, and military developments.

The 1648 Peace of Westphalia symbolized the advent of territorial politics with fixed and relatively hard borders. In previous ages borders represented more geographical zones than clear lines. The Roman concept of limes and the French concept of marches are good examples of such fuzzy borders. The new type of borders resulting from Westphalia was part of the state building process. At that time the ideal of a sovereign state controlling a given territory became prevalent. This was later to be paired with the ideal of the sovereign people carried on the banners of the French and American revolutions. Yet these new borders were not just a consequence of legal treaties. They also depended upon the technological advances and administrative capacities that emerged only in the second part of the nineteenth century with the development of modern forms of transportation (especially railroads), and the successful centralization of government. Only then, according to historians such as Charles Maier, did a new awareness of 'bounded space, a preoccupation with fixing border lines, with the demarcation of insiders and outsiders, public and private', become truly the reality (Maier 
2002). Borders were no longer seen as zones, but as sharp lines separating largely homogenous and centrally governed nation-states. In other words, a strict overlap was provided between administrative borders, military frontiers, cultural traits, and market transaction of individual states.

Of course, control of borders was never absolute even in well-functioning states; nor was the fit between various types of borders. For example, some states were multi-cultural and some nations lived in more than one state or had no state. That said, in the Westphalian era individual states with their central, hierarchical governments were ruling a clearly defined territory in most if not all functional fields. Public authority was much less fragmented and “privatized”, as was the case in the Middle Ages (Kratochwil 1986; Spruyt 1996). Borders became delineated, and defended not just for military reasons, but also economic and cultural ones. Transnational jurisdictions and plural trans-border allegiances became an exception rather than a rule.

Westphalian principles and borders have been formally compromised only with the advent of European integration. Sovereignty was progressively shared and governance was increasingly transnational within an ever larger European space. By the same token, the distinction between what is foreign or domestic has been blurred within the EU with obvious impacts on the nature of borders, especially economic ones. While “internal” EU borders were gradually dismantled, the "external” EU borders were said to be progressively enforced. This was easier said than done because of the ongoing process of EU enlargement. The EU policy of open borders also applied to countries that had little prospect of joining the EU. The European Neighbourhood Policy envisaged the "export” of EU rules to these poor and unstable countries. The more neighbours embraced EU laws and regulations, the more barriers to trans-border cooperation were promised to be lifted. 
This open borders policy has concerned not just the EU, but also its member states. EU internal and external borders are de facto borders of its member states. This is why scholars pointed to a fundamental transformation of these states in the process of European integration; nation-states have become member states with progressively curbed powers, especially over their borders (Bickerton 2013).

Of course, decisions regarding borders have always been sensitive and subject to bargaining. "Front line states" had different perceptions of borders than those less exposed to trans-border flows coming from unstable neighbours. Economists argued that it would be disadvantageous and impractical to hamper cross-border movement of capital, goods, services and labour (eub2 2016; European Commission 2012). Security specialists, on the other hand, contested the notion of open or porous borders (Caparini and Marenin 2006; EUObserver 2016). The hardening of EU borders pleased anti-immigration campaigners, but angered human rights campaigners. The Schengen regime was viewed by some as a symbol of free travel, and by others as symbol of exclusion (Grabbe 2000).

Political leaders shifted between these two extreme positions depending on circumstances and audiences. Each terrorist attack reinforced the notion of sealed borders, but successive political upheavals in neighbouring countries demanded more open borders for either humanitarian or political reasons.

The assumption guiding border politics was that emerging problems are manageable thanks to Europe's sophisticated institutional framework and vast economic resources. This assumption proved overly optimistic. On the one hand, globalization and the digital revolution have made borders more porous. On the other hand, we have observed a retreat to national borders not only in the United Kingdom as a result of the Brexit referendum, but also in such states as France, Italy, Poland, Hungary, or Finland, albeit for different reasons. The scope and significance of these two opposing trends is a matter of debate, but there is an ever more 
widespread feeling that Europe is facing existential dilemmas and some if not most of them relate to borders. Put differently, the tringle - territory, authority, and rights - would have to be re-examined.

\section{Unbounding and rebounding}

We usually are shown two maps of Europe, one with individual nation-states in different colours and another with the EU in blue, surrounded by neighbours with different degree of association. These two maps may not stand the test of history in a few years. The EU is disintegrating and some of the nation states are losing basic attributes of states. Is Greece a state or a protectorate? Will Brexit regain sovereignty for the United Kingdom or cause its disintegration? Is Germany a kind of state like Latvia or Cyprus? These are no longer provocative or speculative questions. The official maps of Europe are no longer in sync with the developments on the ground. On the one hand, states are increasingly unequal and on the other hand, integration along a federal pattern is more illusory than ever (Kelemen 2004). External EU borders are neither fixed nor hard, while internal EU borders are not being progressively abolished.

Europe’s maps became obsolete for good reasons: over the past thirty years we have seen borders changing scope and nature with an impressive force and pace. I call this process unbounding and rebounding. The process has not been linear as old borders have been replaced by new ones with different degrees of success. The process has been conflict-ridden: the "party of territoriality” seeking to restore and reinforce the existing boundaries constantly clashed with the "party of globalization” seeking to overcome geographic boundaries. Numerous factors contributed to unbounding and rebounding, but three of them seem most significant: technological innovation, the quest for profits, and geo-political reordering. 
Let's start with the geopolitical reordering. The fall of Communism in Eastern Europe has restructured geopolitical borders on the old continent. The Soviet Union and Yugoslavia disintegrated, Germany has been reunited and the European Union has been vastly expanded. Territorial borders have been in flux since 1989, producing new states, autonomous enclaves, semi-protectorates, and "shared” neighbourhoods (Hirst 2005; Vasquez and Henehan 2011). Political ideologies, legal rules, and economic systems moved across these fuzzy borders. Many people enthusiastically welcomed new regimes on their territory, but some were forced to flee, if only because of their ethnic background. Some states, alliances, regimes, or ethnic groups have been proclaimed as winners while others have seen themselves as losers. A long-standing balance of power between various groups and units has been effectively reshuffled. The politics of recrimination and violent conflict was part of this process, as currently observed in the Ukraine and earlier in Georgia, Moldova, and Serbia. The reordering of the geopolitical map of Europe has also affected affluent states of Western Europe. Consider for instance the new "balance” of power between France and Germany.

Equally pronounced geopolitical restructuring took part in Europe's southern neighbourhood. After a series of Western military interventions, civil wars, and the Arab Spring we face in this neighbourhood numerous failed or dysfunctional states, Islamic fundamentalism, economic malaise, and refugee flows. These problems can hardly be managed or contained effectively given their scale, complexity, and the lack of adequate governance (Tömmel 2013; Dandashly 2015; Behr 2013). They affect different parts of Europe disproportionately causing frictions not only between EU member states, but also between different national parties and their electorates. This is most visible in the field of migration (Triandafyllido and Gropas 2014; Joppke 2014). Not only “front line states” such as Greece or Italy are facing disproportionate migratory pressures, but also states such as Germany or Sweden that represent the migrants' favourite destination. Domestic political maps are being reshaped as a result with anti- 
establishment and anti-immigrant parties making huge electoral gains in numerous European states, (and not only in those most affected by migration).

At the time that the geo-political map of Europe was unravelling, Europe's leaders negotiated a new treaty that prompted a geo-economic revolution. The 1991 Maastricht Treaty gave a push to opening EU borders to the free movement of goods, capital, people, and services. ${ }^{4}$ Moreover, it led to the creation of the single European currency. These projects represented Europe's response to globalization, or if you wish its own regional version of globalization. $^{5}$

The opening of economic borders within Europe was said to be a win-win-game, but in reality it benefited some spaces, institutions, and social groups more than others (Pisani-Ferry 2014; Offe 2015). The EU has become a crucial center of economic transactions; there are now more than 30,000 lobbyists registered in Brussels trying to influence the decisions of the European Commission in charge of the single market (Rasmussen 2015). The Euro and the single market have also created socio-economic winners and losers (Christopherson, Clark, and Whiteman 2015). Several years ago unemployment in Spain was at a similar level as in Germany, for instance. Today Spain has five times more unemployed people than Germany. Greece and Cyprus are no longer sovereign states, but semi-protectorates run by a consortium of creditor states represented by the IMF and the Euro group. No wonder there is a growing resistance to the politics of open borders in both creditor and debtor states.

The private sector has also expanded at the expense of the public sector with the unravelling of economic borders. Markets and market-values moved into spheres that used to be the domain of the public sector in Europe such as health, education, public safety, environmental protection, and even national security.

The spread of the internet has also intensified the unbounding and rebounding. Some regions, institutions, and social groups benefit from the digital revolution more than others 
(Norris 2000). As we celebrate the $25^{\text {th }}$ anniversary of the World Wide Web we are lamenting the erosion of some of Europe's democratic achievements such as parliamentary representation, quality journalism, and citizens' right to privacy (Keane 2013; Zielonka 2015). Today monitoring of politicians is more serious on the web than in parliaments. Newspapers that used to be the centre of informed public deliberation are in decay. The private data of citizens is being used and misused by internet providers and security agents. The internet does not recognize territorial borders; nor does it respect a border between what is public and private. However, the access to the internet is unequal, both in terms of provision and consumption. Some information is being spread, while other information is being silenced.

All modes of communication are structured by power relations and this is especially the case with the internet. On the one hand, the internet is having a liberating effect: information previously restricted to narrow circles of users can now be broadly shared. On the other hand, the internet is also being used as a tool of propaganda and repression(Morozov 2012; Castells 2011).

The impact of these three dramatic developments taken together is poorly understood, but it is clear that neither the EU nor individual member states are able to cope with it adequately. Germany may well be seen by outsiders as benefiting from the Euro crisis, but this is not necessarily a perspective shared by the German people. As a result, the ruling party of Angela Merkel has lost several local elections ahead of the national electoral test in 2017. Poland grew 25 per cent over the last decade, but the majority of Poles decided to "punish" the ruling elite nevertheless, by giving their vote to a fairly anti-establishment party in the last national elections.

Some shocks and pressures experienced by Europe had a universal character; globalization and digitalization have never been confined to Europe alone. It is also hard to claim that these shocks and pressures are confined to the past three decades. Intense cross- 
border exchanges of goods, services, and finance have certainly accelerated in the late 20th century, but this was also the case during the Italian Renaissance, for example. That said, there is little doubt that the geopolitical restructuring, the single market and currency project, and the advent of the internet affected Europe in profound ways. If one tries to explain the multiple crises Europe faces at present it is impossible to ignore the effects of unbounding and rebounding. In fact, borders and border policies are at the centre of the political contestation at present and the official architectural designs look outdated if not obsolete.

\section{Four spatial paradigms}

If the official architectural designs are outdated, what can replace them? What are possible new constellations of the territory, authority, and rights in Europe? At least four possible paradigms can be deducted from the study of the relevant literature.

The first and most obvious option envisages a spatial construction of Europe along variable geometry. Nation states and European institutions are at the centre of this spatial design. Integration is not a harmonious process, but rather different states integrate at different levels and paces depending on their economic and political circumstances.

This option is anything but revolutionary. Despite the official rhetoric, the EU always acted along concentric circles resembling a variable geometry. EU membership never overlapped with the Euro or Schengen membership. Non-EU members such as Norway or Switzerland adopted much of the EU acquis (Eriksen and Fossum 2015). The crisis of the euro, the results of the Brexit referendum, and the failure of a common policy towards refugees has forced even the most enthusiastic Europeans to accept that the federal architecture is ruined and therefore more flexible spatial arrangements ought to be entertained. However, this new European "realism" is less realistic than it seems. This is because it is not clear whether the EU 
is likely to survive and if it does, it will be largely thanks to Germany and on Germany’s terms. This suggests a fundamentally different European architecture.

The second paradigm is imperial. States in Europe continue to exist, but they have different and often limited ability to exercise their sovereign rights. However, one of them stands above them all and it is able to impose its will on other, formally independent states. Given the current European predicament this is not necessarily bad news. The imperial hegemon may well be able to provide law and order; to shape the rules of internal interdependence; to defend the continent from external predators. There is only one actor currently able to play this imperial role and therefore this imperial architecture may as well be labelled Bundesrepublik Europa or ordo-liberal empire.

This option is also not so revolutionary. Most important European problems are currently being solved in Berlin rather than Brussels. Envoys from other states rush to the German chancellery in search of economic help, diplomatic mediation, and even German intervention to deal with their domestic "trouble makers." Artists also begin to travel en masse to Berlin, Dresden, and Frankfurt in search of inspiration and patronage.

Germany may well be the largest and most potent actor as a result of the post-1989 geopolitical unbounding and rebounding, but it is uncertain whether it is able and willing to reintegrate Europe along the imperial pattern. Moreover, the imperial paradigm does not take into account the unbounding power of globalization which undermines even such effective states as Germany.

This leads us to the third possible design or paradigm, namely of Europe resembling multiple networks. Mega-cities, regions, and firms are at the centre of this paradigm. Integration is chiefly functional rather than territorial and networks are often global rather than European. Instead of well-structured and legally bounded variable geometry we have spontaneous, informal, and hybrid cooperative arrangements between numerous private and public actors. 
Already now major banks form networks with states, cities, and investors across the world to foster a majority of projects, some of broader communal importance (Clark, Wojcik, and Jcik 2007; Fujita, Krugman, and Venables 2001).

The network paradigm does not talk about the withering away of states, but it assumes that most successful states are able to work in sync with the forces of globalization. The network paradigm does not herald the end of European integration, but it assumes that different fields of integration will operate on a different territory, not always confined to Europe as a geographic expression. Nor does the network paradigm proclaim the end of borders; it only claims that borders are fuzzier and softer than it is assumed by the statist paradigm.

The fourth paradigm worth considering stems from the latest developments in digital communication and management (Margetts et al. 2015; Kirman 2010). This paradigm envisages cascading pluralism in contemporary Europe which neither resembles geometry (however variable) nor network (however hybrid). Individuals (citizens, investors, consumers, etc.) acting through social media are at the centre of this paradigm. Internet-based politics and economics enables bottom-up dynamism, blurs organizational boundaries and rebalances power relationships. The absence of organized and institutional actors/groups is striking; for each interest there are constellations of loose mobilizations. Since social media platforms provide “zero-touch” coordination the map of Europe is fairly messy with no "leaders,” hierarchy, and rules. This emerging pluralist pattern is one that is more disorganized, unstable or even chaotic than envisaged by Europe of networks, let alone variable geometry. In fact, it is not sure that this paradigm resembles anything worth the name architecture. Yet it ought to be seriously considered. This is not only because of the impact of the digital revolution. It is also because economic interactions are now more complex and unpredictable than envisaged by the orthodox economic trinity: rationality, selfishness, and equilibrium (Arthur 2014; Beinhocker 2007). If 
this is the case, we need to seriously consider institutional settings that go far beyond the mainstream thinking about a possible and desirable European architecture.

\section{Integration led by states}

We do not have a theory which would help us to assess the feasibility and efficacy of any of the above mentioned paradigms. However, a review of the relevant literature can shed some light on the likelihood of these models and their possible implications. The first two paradigms are statist in a sense that they envisage the leading role of states in forging the integration project. The conception of states is different, however, in Europe of concentric circles than in Europe resembling an ordo-liberal empire. This is partly because the former paradigm emphasizes formal institutional arrangements, while the latter focuses on informal power politics. Political and legal notion of states’ sovereignty is usually different, for instance (Krasner 1999).

The literature in the field of European studies talks at length about different forms of differentiated integration envisaged by our first paradigm. It elaborates on concepts of variable geometry, concentric circles and multi-speed Europe (Hooghe and Marks 2001; Tassinari 2006; Economist 2016).These concepts have also been considered by important European politicians (Fischer 2000; Chirac 2000).

Differentiated integration has always been an important feature of the European Communities and later the European Union, but it was treated as a temporary, if not pathological arrangement. EU experts and officials questioned the efficiency of a Union made up of concentric circles and variable geometric patterns resulting from various opt-outs negotiated by individual member states in the areas of foreign, monetary, or social policy. They believed that European integration should be about increased convergence across various functional fields and within a given territory. This is because individual functional fields impact 
on each other and suggest a unitary governance structure. Scholars argued that differentiated integration complicates or even paralyses decision-making, creates EU members with different rights and obligations, and encourages free riding. It also undermines clarity, transparency and responsibility of individual institutional arrangements. Neil Walker underlined that accountability can hardly be assured in a “crowded institutional context.”(Walker, 2000, 11) Johan P. Olsen warned that citizens' involvement and participation is difficult in large multilevel polities (Olsen 2003). Deidre Curtin (1993, 20) argued that growing fragmentation and differentiation is a sign of “democratic regression”.

It is hard to dismiss all these arguments, but the degree of complexity found within an ever larger European Union has made it hard to get rid of differentiated institutional arrangements. This is why the idea of a "core group” consisting of structurally similar and likeminded states has always been in circulation (Story 1998). It has gained on importance with the creation of the Euro; the Eurozone was seen as a prototype of such a core group manifesting a higher degree of integration than those EU member states which are unable or unwilling to adopt the Euro. The result would be a two-tier Europe which by itself represents a simple version of differentiated integration.

However, the idea of a core Europe could only work if accepted by states who were to remain outside the core. Such an acceptance was never forthcoming as non-Euro states were afraid of being condemned to a peripheral status without a say over important decisions affecting them. A more complex differentiated integration along multiple concentric circles could reduce such fears, because individual states could be part of some integrative schemes while abstaining from others with no sharp border between the centre and the periphery. It could also satisfy a respected group of specialists in public administration in favour of plurilateral governance. In their view an effective system of governance must be able to represent the basic types of variety found in the system to be governed. This means that the more diverse the 
qualities to be governed, the more diverse the necessary governing measures and structures, and the more diverse the relationship between them (Kooiman 2003).

The second, imperial, paradigm is being discussed by sociologists, political scientists, and public commentators who do not belong to the core of EU experts. Yet, the former group includes some of the most renowned academics and public commentators such as Ulrich Beck, Brendan Simms, William Paterson, Martin Wolf, and George Soros. Ulrich Beck(2013a; 2013b) talked about an “accidental” German empire, and William Paterson(2011) labelled Germany a "reluctant hegemon.” Wolf (2012) criticized the asymmetric adjustment process in the Eurozone i.e. deflation in the periphery without inflation in Germany, "this is not a monetary union”, he wrote, “It is far more like an empire.” George Soros(2012) also talked about “a German empire with the periphery as the hinterland.” Empire has also been a recurrent theme in academic journals such as Geopolitics or the Journal of Power; none of them frequently referred to by EU specialists (Parker 2010; Gravier 2015; Colomer 2011).

The imperial paradigm does not only emphasize the growing discrepancy of power within Europe and Germany's ability to impose domestic constraints on other member states within the EU. The imperial paradigm also focuses on the informal structure of governance, the fuzzy nature of borders in Europe, and narratives framing policies, so called civilizing missions. These topics are usually neglected by students of the EU focusing on inter-state bargaining, formal institutions, and national interests. The imperial paradigm questions the notion of sovereignty and it does not differentiate between domestic and foreign affairs the way it is being done by the statist paradigm. Empires hardly ever possess fixed and hard borders and they often find it impractical to differentiate between external and internal policy. Borders between the imperial center and peripheries tend to be ambiguous, with peripheries able to drag the center into their parochial conflicts and extract side-payments (Münkler 2007; Collignon 2007). This explains why students of empires are more at ease explaining the cascading 
economic interdependence, transnational jurisdictions and multiple cultural loyalties than students of inter-state politics and international organizations.

In the current literature Germany is being presented as an empire by default rather than design and clearly different from its earlier incarnations. As Brendan Simms succinctly explained: "the empire in question is not that of the Kaiser or Hitler but the old Holy Roman empire, whose strengths and weaknesses live on in the European Union of today. Instead of anchoring the common currency in joint parliamentary representation and a strong state capable of efficient revenue extraction as is the case in the United Kingdom and the United States, Berlin is attempting to run it through the acceptance of German "rules” and political culture. Instead of a single foreign policy and military capable of deterring aggressors, we have a perpetual palaver that reminds one of nothing so much as the equivocations of the Holy Roman empire in the face of Turkish or French threats.”(Simms 2015)

The problem is that neither Germany nor its neighbors can ignore the German infamous imperial history. Moreover, an informal rule does not bode well for the functioning of democracy. In fact, Germany has the propensity to legalize all kind of arrangements and it is difficult to envisage a constitutional arrangement which would grant Germany formal powers to rule the entire continent. The Fiscal Compact Treaty has imposed on "peripheral" states relatively minor restrictions and it has been fiercely contested nevertheless (Darnstädt 2011; Economist 2011). Moreover, Germany can only act as an imperial engine of integration if it commits sizable resources for realizing a plausible European project. So far Germany’s policies towards Europe have shown little sense of direction and scant willingness to invest adequate financial resources in any common endeavour. Ordo-liberal economic policies have condemned the southern periphery to poverty with no visible gains for Germany and other creditor nations. Germany’s migration policies have also proved ineffective and controversial despite the alleged good intentions. 
In sum, the ordo-liberal empire seems more a reflection on the current pathologies within the EU than a workable proposition for a durable integrative project.

\section{Integration led by firms, cities, and NGOs}

So far, European integration has been led by nation states, but the current crisis questions states' continuous ability to act as an engine of integration. In fact, it can be argued that the required next integrative step would amount to a virtual suicidal for states. For instance, ceding some crucial fiscal and macro-economic prerogatives to the European center would leave nation states with no means to forge independent social policies. But many experts argue that without a genuine economic governance the single currency cannot work (Pickford and Royal Institute of International Affairs 2014). This suggests that the current model of integration is unsustainable and if so, alternative integrative arrangements led by other actors than nation states ought to be considered.

EU experts are by and large reluctant to entertain such alternative arrangements, but a study of the literature in the field of political and financial geography, complex sociology and economics, urban and communication studies suggests two possible non-statist paradigms of integration, one of functional networks, and another of cascading pluralism. This rich body of literature points to the fact that states have never been the sole actors behind European integration. The federal project was invented and promoted by progressive intellectuals and not government officials; in fact, integration was aimed at taming states' hegemonic ambitions and at empowering European citizens instead (Spinelli and Rossi 2006; Deutsch 1957). Firms were also important engines of integration. The fact that integration evolved more in the field of economics than in the field of defense or social policy, bears witness to this claim (Strange 1998).There is also a growing body of evidence pointing to a growing role of cities and NGOs, 
both acting in a transnational framework (Herrmann 1998; Joachim and Dembinski 2011; Evgeniy 2016).

The literature mentioned suggests that unbounding prevails over rebounding. In other words, internationalization of economic transactions, communication, and culture is progressing despite efforts to tame or reverse it. As a consequence, we observe rising plurality and hybridity. Europe’s societies are becoming more heterogeneous, more mobile, and more informed. Economic inequality within and between states is progressing generating a very diversified map of power and powerlessness. Europe is increasingly looking like a mosaic of semi-imperial and semi-dysfunctional states living next to each other, successful and failed cities and regions, capricious firms and erratic NGOs. We can already observe a multiplication of various complex institutional arrangements operating on the overlapping territorial spaces as well as the increased plurality of different types of authority with uneven geographic reach, material capacity, and political legitimacy. Communicative abundance facilitates the rise of new ideologies competing for followers. Economic globalisation increases pressures on territorial units hosting and regulating competing firms. The outcomes are anything but straightforward, with Europe increasingly resembling a maze.

However, plurality and hybridity does not need to lead to chaos. A complex system is not a synonym of anarchy and confusion. Order and chaos are relative terms. As Herman van Gunsteren (1998, 116) put it: "Where one person sees plurality, the other one sees rubbish. Where one person sees variety, another sees disorder. Where the one sees monsters (unacceptable combinations such as centaurs), the other sees fascinating novelties.”

Some argue that all social systems tend towards atomization and anarchy while others believe that even the most chaotic systems are able to generate a dynamic order (Prigogine, Stengers, and Toffler 1984). What one person sees as a way of recognizing change and plurality, another 
sees as a recipe for disorder encouraging free riding. Hierarchical systems are not always stable and efficient.

An effective system of governance does not need to be state-based or state-centric. (And the concept of state needs to be located socially, disaggregated institutionally, and reorganized into its various component policy networks) (Pierre 2000). An effective system of governance does not even need to be territorial or territorially fixed. (And the concept of territorial governance need not entail mutual exclusion) (Ruggie 1993, 148). Such thinking is common among specialists of complex societies, economics and organizations, but it is alien to specialists of European integration (Kirman 2016; Walby 2007). There is no reason to believe that European integration ought to be run by states in a centralized and highly institutionalized manner.

This leads us to the paradigm of Europe integrated along functional networks. Networks have been brought to a wider academic discourse by the work of Jan van Dijk(2005) and Manuel Castells (2009) arguing that the key social structures and activities are organized around electronically processed information networks. Specialists in urban and regional studies have also seen nodes, flows, and networks rather than traditional states as key agents of connectivity (Pain et al. 2015). The spectacular rise of global financial networks concentrated in mega-cities should be considered here. In 1990 the wealth of the financial sector was estimated at some \$ 54 trillion. In the next seventeen years it almost quadrupled, to \$ 202 trillion by 2007. Since then the growth rate has slowed, but not stopped or reversed as was the case in many other sectors (Davies 2015, 8).

Today trans-national corporations interact through a multitude of formal and informal institutions, some international, some national and some local (including business customs) (Wójcik 2017, 4). The map of major business and legal links looks totally different to the map of the EU. London, Amsterdam and Luxemburg are key players in financial markets, not 
Brussels or even Frankfurt. Financial, business, and legal networks practice a different type of integration than currently offered by the EU. This integration is more functional than territorial, it is less institutionalized and more dynamic. In time, it can well represent a prototype of a new mode of integration resulting from progressive economic unbounding.

However, one cannot exclude a scenario of an even less structured form of integration and hence the fourth paradigm of cascading pluralism. This is partly because cities, NGOs, or firms can only offer certain type of services. For instance, cities can act as Europe’s capitals of finance, education, and media, but they are unlikely to be the centres of traditional military power. Moreover, the Internet offers citizens numerous cross border opportunities to align and rebel. And in the absence of a strong European centre we can expect different actors to seek support from a variety of public authorities on a European, national, and local level (and possibly also from new transnational NGOs specialized in welfare provision). Gaps between affluent city conglomerations and impoverished provinces will widen. Farm belts will find it more difficult to stay on par with manufacturing and servicing belts. Some regions with global communication links will thrive while others will falter. All this would mean that integration will be more plurilateral and hybrid than in the case of functional networks.

Needless to say both of these paradigms create transparency and accountability

dilemmas. However, power would be more disperse than is the case in the two previous paradigms. Networks watch each other's moves and publicize abuses of power. Enhanced forms of communication will hopefully help to enhance transparency and monitor abuses of power.

\section{Conclusion}

Some persons, including academics believe that Europe and the world will stay more or less as it is in the next few decades. In their view, globalization, communication, and hybridisation are constant features of European polities, and unbounding and rebounding simply cancel each 
other out, leaving nation states largely unhurt. This article argued that it is impossible to explain the series of existential crises confronting present-day Europe without reference to the changing nature of borders. Unbounding and rebounding prompted by transnational and technological pressures reconfigures the relationship between territory, authority, and rights in Europe. It makes the current project of European integration unsustainable and forces us to search for new cooperative arrangements. Four such hypothetical arrangements have been considered by this article. Although the first paradigm of variable geometry seems most realistic at present, two decades from now we may well conclude that functional networks are true engines of integration with nation states playing supporting rather than the leading role.

Europe is likely to integrate further, but not necessarily in ways we are able to envisage right now. Comprehending the ongoing unbounding and rebounding can stimulate our imagination. This article is an invitation to stretch our imagination with the help of literature outside the European studies academic field.

\section{Notes}

${ }^{1}$ As Pierre Manent (1996, 7-8) put it: “Instituting a political order, prior to consulting the will of any individuals, requires first the staking out of a common territory. A common territory is the barest requirement of a political community, to be sure, but it is also in a sense the most necessary.... While I readily admit that one can renounce the nation as a political form, I do not believe that people can live long within civilization alone without some sense of political belonging (which is necessarily exclusive), and thus without some definition of what is held in common."

${ }^{2}$ Unbounding is a process during which the existing boundaries either wither, move or change nature. Rebounding is the opposite process; boundaries are being restored both in terms of scope and nature. When different types of borders are being removed or softened then we can talk about unbounding. Efforts to reverse unbounding represent rebounding.

${ }^{3}$ The literature often uses the terms 'border,' 'frontier', and 'boundary' as synonyms, but their meanings vary. According to Malcolm Anderson (1996, 9) , for instance, 'frontier' has the widest meaning (line or region); 'border' can be a narrow zone or a line of demarcation; 'boundary' is a line of delimitation only.

4 A "Common Market" had already been established in the 1957 Treaty of Rome, but the "single market" formally came into being in 1993. For a detailed historical overview see: http://ec.europa.eu/internal_market/top_layer/historical_overview/index_en.htm.

${ }^{5}$ Some activists and experts have criticized the EU for acting as an engine of globalization and an agent of multinational firms. Others lamented that the EU has failed to protect its population from globalization. As Larry Elliott (2016) put it in the context of the post-Brexit debate: 
"Europe has failed to fulfil the historic role allocated to it. An increasing number of voters believe there is not much on offer from the current system. They think globalisation has benefited a small privileged elite, but not them. They think it is unfair that they should pay the price for bankers' failings. They hanker after a return to the security that the nation state provided, even if that means curbs on the core freedoms that underpin globalisation, including the free movement of people." 


\section{References}

Anderson, Malcolm. 1996. Frontiers: Territory and State Formation in the Modern World. Polity Press.

Arthur, W. Brian. 2014. Complexity and the Economy. 1 edition. Oxford ; New York: Oxford University Press.

Beck, Ulrich. 2013a. 'Germany Has Created An Accidental Empire'. Social Europe. March 25. https://www.socialeurope.eu/2013/03/germany-has-created-an-accidental-empire/.

Beck, Ulrich. 2013b. German Europe. Translated by Rodney Livingstone. 1 edition. Cambridge, UK ; Malden, MA: Polity.

Behr, Timo. 2013. 'EU Foreign Policy and Political Islam: Towards a New Entente in the Post-Arab Spring Era?' The International Spectator 48 (1): 20-33. doi:10.1080/03932729.2013.758905.

Beinhocker, Eric D. 2007. The Origin of Wealth: The Radical Remaking of Economics and What It Means for Business and Society. 1 edition. Boston: Harvard Business Review Press.

Bickerton, Chris J. 2013. European Integration: From Nation-States to Member States. 1 edition. Oxford, United Kingdom: Oxford University Press.

Caparini, Marina, and Otwin Marenin. 2006. Borders and Security Governance: Managing Borders in a Globalised World. LIT Verlag Münster.

Castells, Manuel. 2009. The Rise of the Network Society: The Information Age: Economy, Society, and Culture Volume I. 2 edition. Chichester, West Sussex; Malden, MA: Wiley-Blackwell.

Castells, Manuel. 2011. Communication Power. 2 edition. Oxford: Oxford University Press.

Chirac, Jacques. 2000. 'Address given by Jacques Chirac to the Bundestag Entitled Our Europe (Berlin, 27 June 2000)'. Cvce.eu.

http://www.cvce.eu/en/obj/address_given_by_jacques_chirac_to_the_bundestag_entitled_ our_europe_berlin_27_june_2000-en-6a747c46-88db-47ec-bc8c-55c8b161f4dc.html.

Christiansen, Thomas, and Knud Erik Jørgensen. 2000. 'Transnational Governance "above" and "below" the State: The Changing Nature of Borders in the New Europe'. Regional \& Federal Studies 10 (2): 62-77. doi:10.1080/13597560008421120.

Christopherson, Susan, Gordon L. Clark, and John Whiteman. 2015. 'Introduction: The Euro Crisis and the Future of Europe'. Journal of Economic Geography, July, Ibv026. doi:10.1093/jeg/lbv026.

Clark, Gordon L., Darius Wojcik, and Darius W. Jcik. 2007. The Geography of Finance: Corporate Governance in a Global Marketplace: Corporate Governance in the Global Marketplace. Oxford ; New York: OUP Oxford.

Collignon, Stefan. 2007. Bundesrepublik Europa?: die demokratische Herausforderung und Europas Krise. Vorwärts Buch.

Colomer, Josep M. 2011. 'The Building of the American and European Empires'. Journal of Political Power 4 (3): 395-411. doi:10.1080/2158379X.2011.628853.

Curtin, Deirdre. 1993. 'The Constitutional Structure of the Union\&\#58; A Europe of Bits and Pieces'. Common Market Law Review 30 (1): 17-69.

Dandashly, Assem. 2015. 'The EU Response to Regime Change in the Wake of the Arab Revolt: Differential Implementation'. Journal of European Integration 37 (1): 37-56. doi:10.1080/07036337.2014.975988.

Darnstädt, Thomas. 2011. 'More Problems than Answers: The Pitfalls of the Merkozy Fiscal Pact'. Spiegel Online. http://www.spiegel.de/international/europe/more-problems-than-answersthe-pitfalls-of-the-merkozy-fiscal-pact-a-803923.html.

Davies, Howard. 2015. Can Financial Markets Be Controlled? 1 edition. Cambridge, UK ; Malden, MA: Polity.

Deutsch, Karl Wolfgang. 1957. Political Community and the North Atlantic Area: International Organization in the Light of Historical Experience. Princeton University Press.

Dijk, Jan van. 2005. The Network Society: Social Aspects of New Media. SAGE. 
Economist. 2011. 'Beware the Merkozy Recipe'. The Economist, December 10. http://www.economist.com/node/21541405.

Economist 2016. 'The Charms of Variable Geometry'. The Economist, June 11. http://www.economist.com/news/britain/21700384-our-final-brexit-brief-arguesmultispeed-europe-suits-britainand-others-charms.

Elliott, Larry. 2016. 'Brexit Is a Rejection of Globalisation'. The Guardian, June 26, sec. Business. https://www.theguardian.com/business/2016/jun/26/brexit-is-the-rejection-ofglobalisation.

Eriksen, Erik Oddvar, and John Erik Fossum, eds. 2015. The European Union's Non-Members: Independence under Hegemony? London; New York: Routledge.

eub2. 2016. 'EU Single Market - Benefits - EUbusiness.com | EU News, Business and Politics'. Guide. Accessed November 28. http://www.eubusiness.com/topics/sme/eu-single-marketguide/.

EUObserver. 2016. 'Terrorists Gain “Advantage” from EU Open Borders'. Accessed November 28. https://euobserver.com/migration/133123.

European Commission. 2012. 'Twenty Years of the European Single Market'.

Evgeniy, Dovbysh. 2016. 'Participation of Cities in the EU Integration Processes'. World Economy and International Relations, no. 1, vol. 60: 93-102.

Fischer, Joschka. 2000. 'Speech by Joschka Fischer on the Ultimate Objective of European Integration (Berlin, 12 May 2000)'. Cvce.eu.

http://www.cvce.eu/en/obj/speech_by_joschka_fischer_on_the_ultimate_objective_of_eur opean_integration_berlin_12_may_2000-en-4cd02fa7-d9d0-4cd2-91c9-2746a3297773.html.

Fujita, Masahisa, Paul Krugman, and Anthony J. Venables. 2001. The Spatial Economy: Cities, Regions, and International Trade. Cambridge, Mass.: The MIT Press.

Grabbe, Heather. 2000. 'The Sharp Edges of Europe: Extending Schengen Eastwards'. International Affairs (Royal Institute of International Affairs 1944-) 76 (3): 519-36.

Gravier, Magali. 2015. 'Imperial Governance: Governing Inwards or Outwards?' Geopolitics 20 (4): 814-35. doi:10.1080/14650045.2015.1065485.

Gunsteren, Herman R. van. 1998. A Theory of Citizenship: Organizing Plurality in Contemporary Democracies. Westview Press.

Herrmann, Peter. 1998. European Integration Between Institution Building and Social Process: Contributions to the Theory of Modernisation and Ngos in the Context ...the Eu. Commack, N.Y: Nova Science Publishers.

Hirst, Paul. 2005. Space and Power: Politics, War and Architecture. 1 edition. Cambridge ; Malden, MA: Polity Press.

Hooghe, Liesbet and Gary Marks. 2001. Multi-level Governance and European Integration. Oxford: Rowman and Littlefield.

Joachim, Jutta, and Matthias Dembinski. 2011. 'A Contradiction in Terms? NGOs, Democracy, and European Foreign and Security Policy'. Journal of European Public Policy 18 (8): 1151-68. doi:10.1080/13501763.2011.615204.

Joppke. 2014. 'European Immigrant Integration after Multiculturalism'. In Global and Asian Perspectives on International Migration, by Graziano Battistella. London: Springer.

Keane, John. 2013. Democracy and Media Decadence. First Edition edition. Cambridge ; New York: Cambridge University Press.

Kelemen, R. Daniel. 2004. The Rules of Federalism: Institutions and Regulatory Politics in the EU and Beyond. Cambridge, Mass: Harvard University Press.

Kirman, Alan. 2010. Complex Economics: Individual and Collective Rationality. London ; New York, NY: Routledge.

Kirman, Alan. 2016. 'Complexity and Evolution'. MIT Press. Accessed November 28. https://mitpress.mit.edu/books/complexity-and-evolution.

Kooiman, Jan. 2003. Governing as Governance. SAGE Publications. 
Krasner, Stephen D. 1999. Sovereignty: Organized Hypocrisy. Princeton University Press.

Kratochwil, Friedrich. 1986. 'Of Systems, Boundaries, and Territoriality: An Inquiry into the Formation of the State System'. World Politics 39 (1): 27-52. doi:10.2307/2010297.

Maier, Charles E. 2002. 'Does Europe Need a Frontier?: From Territorial to Redistributive Community'. In Europe Unbound. Enlarging and Reshaping the Boundaries of the European Union, by Jan Zielonka, 17-37. London: Routledge.

Manent, Pierre, and Philip J. Costopoulos. 1996. 'On Modern Individualism'. Journal of Democracy 7 (1): 3-10. doi:10.1353/jod.1996.0012.

Margetts, Helen, Peter John, Scott Hale, and Taha Yasseri. 2015. Political Turbulence: How Social Media Shape Collective Action. Princeton, New Jersey: Princeton University Press.

Morozov, Evgeny. 2012. The Net Delusion: The Dark Side of Internet Freedom. Reprint edizione. New York: Public Affairs.

Münkler, Herfried. 2007. Empires: The Logic of World Domination from Ancient Rome to the United States. Translated by Patrick Camiller. Cambridge ; Malden, MA: Polity Press.

Norris, Pippa. 2000. 'The Internet in Europe: A New North-South Divide?' The Harvard International Journal of Press/Politics 5 (1): 1-12. doi:10.1177/1081180X00005001001.

Offe, Claus. 2015. Europe Entrapped. 1 edition. Cambridge ; Malden, MA: Polity.

Olsen, Johan P. 2003. 'What Is a Legitimate Role for Euro-Citizens?' Comparative European Politics 1 (1): 91-110. doi:10.1057/palgrave.cep.6110001.

Pain, Kathy, Gilles Van Hamme, Sandra Vinciguerra, and Quentin David. 2015. 'Global Networks, Cities and Economic Performance: Observations from an Analysis of Cities in Europe and the USA'. Urban Studies, March, 0042098015577303. doi:10.1177/0042098015577303.

Parker, Noel. 2010. 'Empire as a Geopolitical Figure'. Geopolitics 15 (1): 109-32. doi:10.1080/14650040903420412.

Paterson, William E. 2011. 'The Reluctant Hegemon? Germany Moves Centre Stage in the European Union*'. JCMS: Journal of Common Market Studies 49 (September): 57-75. doi:10.1111/j.1468-5965.2011.02184.x.

Pickford, Stephen, and Royal Institute of International Affairs. 2014. How to Fix the Euro: Strengthening Economic Governance in Europe.

Pierre, Jon, ed. 2000. Debating Governance: Authority, Steering, and Democracy. 1 edition. Oxford ; New York: Oxford University Press.

Pisani-Ferry, Jean. 2014. The Euro Crisis and Its Aftermath. New York: OUP USA.

Prigogine, Ilya, Isabelle Stengers, and Alvin Toffler. 1984. Order Out of Chaos. First Edition edition. New York, N.Y.: Bantam.

Rasmussen, Maja Kluger. 2015. 'The Battle for Influence: The Politics of Business Lobbying in the European Parliament'. SSRN Scholarly Paper ID 2562647. Rochester, NY: Social Science Research Network. https://papers.ssrn.com/abstract=2562647.

Ruggie, John Gerard. 1993. 'Territoriality and Beyond: Problematizing Modernity in International Relations'. International Organization 47 (1): 139-74.

Sassen, Saskia. 2008. Territory, Authority, Rights: From Medieval to Global Assemblages. Updated ed. edition. Princeton, N.J.: Princeton University Press.

Simms, Brendan. 2015. 'Germany's Triumph: From the Ruins of War, How a New European Empire Was Built'. New Statesman, July. http://www.newstatesman.com/politics/2015/07/germany-s-triumph-ruins-war-how-neweuropean-empire-was-built.

Soros, George. 2012. 'Remarks Delivered at the Festival of Economics'. June 2. https://www.georgesoros.com/essays/remarks_at_the_festival_of_economics_trento_italy/

Spinelli, Altiero, and Ernesto Rossi. 2006. Il Manifesto Di Ventotene. Mondadori.

Spruyt, Hendrik. 1996. The Sovereign State and Its Competitors: An Analysis of Systems Change. Reprint edition. Princeton, N.J.: Princeton University Press. 
Story, Jonathan. 1998. '“The Idea of the Core: The Dialectics of History and Space,"'. In Politics of European Treaty Reform, by Geoffrey Edwards, First Edition edition. Boston: Bloomsbury Academic.

Strange, Susan. 1998. States and Markets: 2nd Edition. A\&C Black.

Tassinari, Fabrizio. 2006. 'Variable Geometries: Mapping Ideas, Institutions and Power in the Wider Europe. CEPS Working Document, No. 254, 30 November 2006'. Working Paper. Centre for European Policy Studies, Brussels. http://aei.pitt.edu/7378/.

Tömmel, Ingeborg. 2013. 'The New Neighborhood Policy of the EU: An Appropriate Response to the Arab Spring?' Democracy and Security 9 (1-2): 19-39. doi:10.1080/17419166.2012.736306.

Triandafyllido, Anna, and Ruby Gropas. 2014. European Immigration : A Sourcebook. Second Edition. Ashgate. http://cadmus.eui.eu//handle/1814/30557.

Tsoukalis, Loukas. 2016. In Defence of Europe : Can the European Project Be Saved? Oxford University Press.

Vasquez, John A., and Marie T. Henehan. 2011. Territory, War, and Peace. Routledge.

Verhofstadt, Guy. 2017. Europe's Last Chance: Why the European States Must Form a More Perfect Union.

Walby, Sylvia. 2007. 'Complexity Theory, Systems Theory, and Multiple Intersecting Social Inequalities'. Philosophy of the Social Sciences 37 (4): 449-70. doi:10.1177/0048393107307663.

Walker, Neil. 2000. '“Flexibility within a Metaconstitutional Frame',. In Constitutional Change in the EU: From Uniformity to Flexibility?, by Gráinne De Búrca. Hart Publishing.

Wójcik, Dariusz. 2017. 'The Global Financial Networks'. In New Oxford Handbook of Economic Geography, edited by Gordon L. Clark, Meric Gertler, Maryann Feldman, and Dariusz Wójcik. Oxford University Press.

Wolf, Martin. 2012. 'What Hollande Must Tell Germany'. Financial Times. https://www.ft.com/content/51bf429c-98f8-11e1-948a-00144feabdc0.

Zielonka, Jan, ed. 2015. Media and Politics in New Democracies: Europe in a Comparative Perspective. 1 edition. Oxford: Oxford University Press. 